\title{
Think Global - Act Local: Intravitreal Drug Delivery Systems in Chronic Noninfectious Uveitis
}

\author{
Dicle Hazirolan $^{\mathrm{a}} \quad$ Uwe Pleyer $^{\mathrm{b}}$ \\ a Department of Ophthalmology, Ankara Training and Research Hospital, Ministry of Health, Ankara, Turkey; \\ ${ }^{b}$ Department of Ophthalmology, Campus Virchow Clinic, Charité Hospital, Humboldt University, Berlin, Germany
}

\section{Key Words}

Chronic noninfectious uveitis $\cdot$ Corticosteroids $\cdot$ Intravitreal drug delivery

\begin{abstract}
The eye is probably the most attractive site of the body for treatment using locally delivered therapeutic agents. An ideal indication for such an approach is noninfectious posterior uveitis. Since intraocular structures of the posterior segment are difficult to reach and are otherwise accessible only by systemic treatment, current interest is focused on the pros and cons of intravitreal drug delivery. Because of its chronic and recurrent nature, the long-term release of anti-inflammatory agents is a major treatment goal. Intravitreal injections, intravitreal implants and biodegradable devices are the most commonly used and approved approaches to deliver various agents to the vitreous. Because of their broad and potent effects, corticosteroids (CS) have been the firstline candidates for intraocular delivery. An increasing spectrum of CS preparations including nondegradable and biodegradable devices is currently available. Since repeated and long-term applications bear the risk of steroid-related complications such as increased intraocular pressure and cataract, alternative agents are currently being tested. Intravitreal injection of methotrexate, anti-VEGF (vascular endothelial growth factor), anti-TNF $\alpha$ (tumor necrosis factor $\alpha$ )
\end{abstract}

and sirolimus have also been applied in patients with conflicting results. Intravitreal treatment has significantly reduced the incidence of adverse effects compared to systemic application, but due to greater ocular side effects there are still some limitations.

Copyright $\odot 2012$ S. Karger AG, Basel

\section{Introduction}

Treatment of chronic noninfectious posterior uveitis (CNIU) remains a challenge. Even when CNIU comprises a large spectrum of disorders (often considered as individual entities), initial treatment is predominantly based on corticosteroids (CS). It has been proposed that up to two thirds of patients with posterior uveitis can be controlled on CS alone. However, long-term applied systemic CS cause serious adverse effects to develop in many patients, and immune modulatory treatment is commonly suggested as a CS-sparing approach. While immune modulatory agents can be very effective, they may have serious and potentially life-threatening adverse effects, including renal and hepatic failure and bone marrow suppression. The intravitreal administration of anti-inflammatory medications is, therefore, an attempt to decrease the risks associated with systemic application and to increase the availability of drugs to the posterior segment

\section{KARGER}

Fax +4161306 1234

E-Mail karger@karger.ch

www.karger.com
(C) 2012 S. Karger AG, Basel

0030-3747/13/0492-0059\$38.00/0

Accessible online at:

www.karger.com/ore
Prof. Dr. med. Uwe Pleyer, FEBO

University-Eye Clinic Charité, CVK

Humboldt University

Augustenburger Platz 1, DE-13353 Berlin (Germany)

E-Mail uwe.pleyer@charite.de 
Table 1. Pharmacokinetics and features of intravitreal CS

\begin{tabular}{|c|c|c|c|c|}
\hline & $\begin{array}{l}\text { Kenalog }^{\circledR} \\
\text { (triamcinolone acetonide) }\end{array}$ & $\begin{array}{l}\text { Retisert }^{\circledR} \\
\text { (fluocinolone acetonide) }\end{array}$ & $\begin{array}{l}\text { Ozurdex }^{\circledR} \\
\text { (dexamethasone) }\end{array}$ & $\begin{array}{l}\text { Iluvien }{ }^{\circledR} \\
\text { (fluocinolone acetonide) }\end{array}$ \\
\hline Water solubility, $\mu \mathrm{g} / \mathrm{ml}$ & 21 & 50 & 100 & 50 \\
\hline Half-life in human vitreous (solubilized) & 18 days & $2-3 \mathrm{~h}$ & $3.5 \mathrm{~h}$ & $2-3 \mathrm{~h}$ \\
\hline Relative potency & $1 \times$ & $0.4 \times$ & $3-5 \times$ & $0.4 \times$ \\
\hline Drug kinetics (elimination) & First order & Zero order & First order & Zero order \\
\hline Delivery to the vitreous & Nonsurgical & Surgical & Nonsurgical & Nonsurgical \\
\hline Off-label & Off-label & $\begin{array}{l}\text { FDA-approved; } \\
\text { not EMA approved }\end{array}$ & FDA/EMA-approved & $\begin{array}{l}\text { EMA-approved } \\
\text { (DME); } \\
\text { not FDA-approved }\end{array}$ \\
\hline
\end{tabular}

EMA = European Medicines Agency; FDA = Food and Drug Administration. DME= Diabetic macular edema.

of the eye. However, a number of important considerations have to be taken into account.

- Can we expect that intravitreal therapy will control an immune-mediated disorder - when specific (circulating) immune cells are considered to be important [1]?

- How do we deal with uveitis patients affected by systemic disease, e.g. sarcoidosis, but predominantly suffering from uveitis?

Conversely:

- How can we balance and compare the well-known adverse effects of local CS such as increase in intraocular pressure (IOP) and cataract formation versus systemic side effects related to steroid and immunsuppressive therapy?

- Are we on the right track using 'old' agents (CS) at a time when 'biologics' and 'small molecules' are gaining in importance?

Important answers to these questions have recently derived from recent trials $[2,3]$. Observations indicate that both approaches, intravitreal and systemic CS are successful in controlling inflammation in most patients. However, intravitreal CS more often take effect significantly faster. In addition, vision-related quality of life, an important issue in our mainly young patients, improved significantly within 6 months following intravitreal therapy. These positive features vanished over time, however, and at the 24-month follow-up, both groups had equally improved. More eyes that received long-term intravitreal CS had to undergo cataract and glaucoma surgeries [4]. Even when these adverse effects are related to the features of this particular CS implant, identification of predisposing risk factors, e.g. for developing glaucoma, remains important [5].
Interestingly, the Multicenter Uveitis Steroid Treatment trial also revealed that patients receiving aggressively CS-sparing therapy and prednisone doses of less than $10 \mathrm{mg} /$ day had a low risk of systemic adverse events [2]. Therefore, the choice of treatment for each individual patient needs to be balanced on the advantages and disadvantages identified with each therapeutic option. Taking these considerations into account, a treatment algorithm might be suggested (fig. 1). In this 'mini-review', we intend not only to focus on the increasing spectrum of intravitreally delivered drugs in humans, but also briefly touch on the issue of balancing the risks and benefits of intravitreal compared to systemic treatment.

\section{Corticosteroids}

Notably, even when the addition of immunosuppressive agents is often effective as a CS-sparing approach, most patients do not achieve visual improvement [6]. Therefore, attempts to achieve effective CS levels in the vitreous and retina remain an important treatment goal. Intraocular CS have been used to treat posterior uveitis and inflammatory chronic cystoid macular edema (CME) [7]. Experimental and clinical data indicate that the direct administration of steroids such as triamcinolone into the vitreous cavity has a significant advantage of delivering medication to the posterior segment, i.e. significantly higher concentrations for the adequate treatment of posterior segment inflammation can be reached [8]. However, frequent injections are often needed to maintain drug concentrations within a therapeutic range. Additionally, pharmacokinetics and features differ according to the type of the intravitreal CS (table 1). 


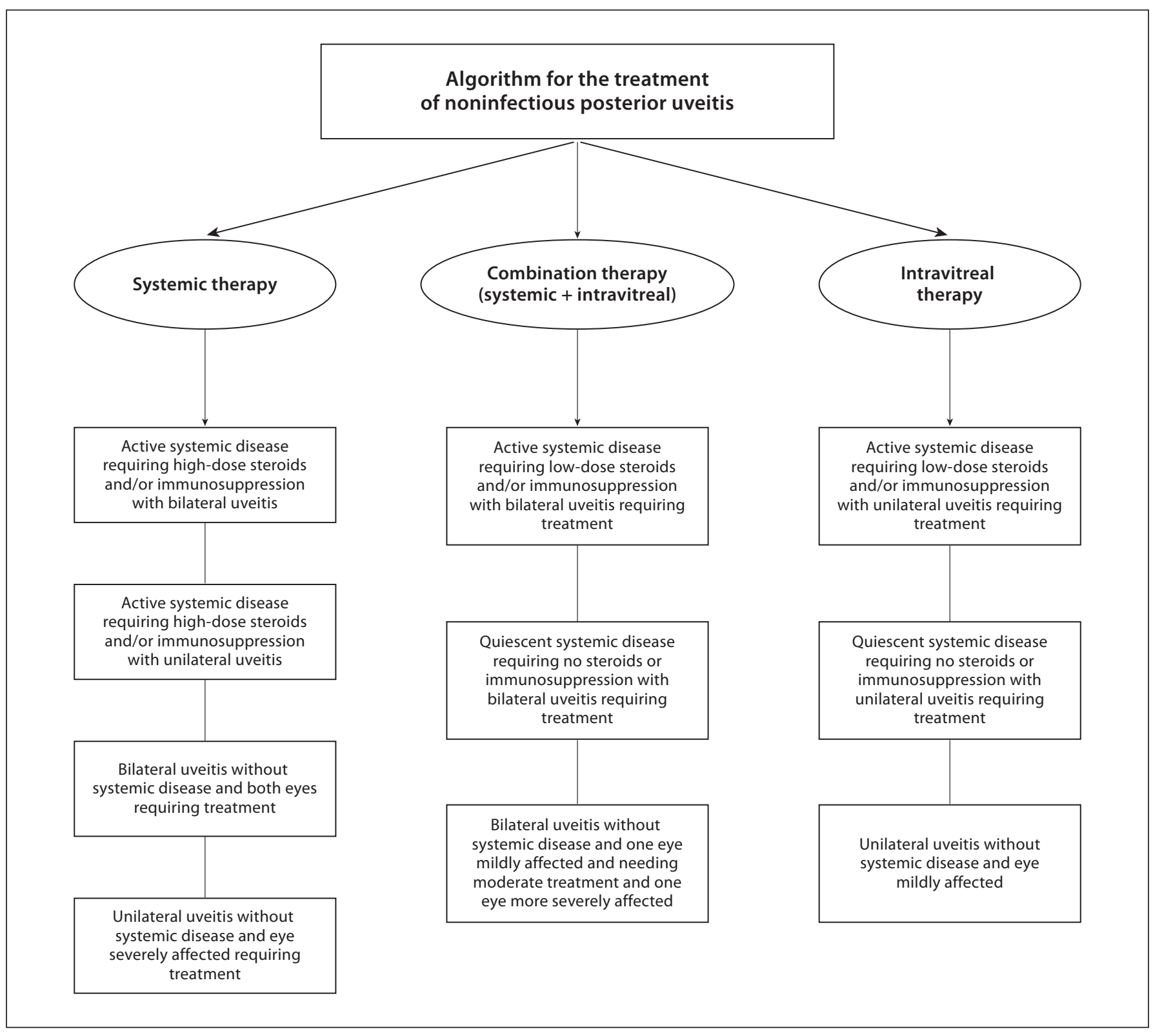

Fig. 1. Algorithm for the treatment of CNIU.

\section{Intravitreal Triamcinolone Acetonide Injection}

Intravitreal triamcinolone (IVTA) reduces CME and vitritis and improves vision, usually at a dose of 2-4 $\mathrm{mg}$ [9-11]. Behçet's disease, sarcoidosis ,Vogt-Koyanagi-Harada syndrome and sympathetic ophthalmia, are among others effectively treated with IVTA [11-14]. Even in such disorders, considered to be autoimmune-driven, a beneficial effect could be achieved. Cataract and glaucoma are frequent complications of IVTA (table 2) [9]. The risk of cataract formation and elevated IOP increases with repeat injections, and these are more pronounced in children $[9,15]$. Furthermore, intravitreal injection of CS should not be used in infectious uveitis as serious consequences could result $[16,17]$.

\section{Intravitreal Corticosteroid Implants}

Repeated episodes of intraocular inflammation are known to result in cumulative damage to the retina [18, 
Table 2. Comparison of intravitreal drug delivery systems used in CNIU

\begin{tabular}{|c|c|c|c|c|c|c|}
\hline & Matrix & $\begin{array}{l}\text { Duration of } \\
\text { effect, months }\end{array}$ & $\begin{array}{l}\text { Improvement in visual } \\
\text { acuity }\end{array}$ & $\begin{array}{l}\text { Tapered systemic } \\
\text { medications }\end{array}$ & Glaucoma surgery & Cataract surgery \\
\hline $\begin{array}{l}\text { Kenalog }^{\circledR} \text { (4-mg triamcinolone } \\
\text { acetonide intravitreal injection) }\end{array}$ & - & $3-7$ & $\begin{array}{l}51 \% \text { gained at least } 2 \\
\text { Snellen lines by week } 4\end{array}$ & yes & $\begin{array}{l}1-2 \% \text { (risk } \\
\text { increases with } \\
\text { repeat injections) }\end{array}$ & $\begin{array}{l}15-30 \% \text { (risk } \\
\text { increases with } \\
\text { repeat injections) }\end{array}$ \\
\hline $\begin{array}{l}\text { Retisert }^{\circledR}(0.59 \text {-mg fluocinolone } \\
\text { acetonide implant })^{\mathrm{a}}\end{array}$ & $\begin{array}{l}\text { nonbiodegra- } \\
\text { dable }\end{array}$ & $24-36$ & $\begin{array}{l}21 \% \text { gained at least } 15 \\
\text { letters by week } 34\end{array}$ & yes & $30.6 \%$ by month 24 & $93-100 \%$ \\
\hline 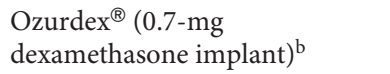 & biodegradable & $4-6$ & $\begin{array}{l}38 \% \text { gained at least } 15 \\
\text { letters by week } 26\end{array}$ & yes & $0-0.5 \%$ & $0-4 \%$ \\
\hline $\begin{array}{l}\text { Iluvien }{ }^{\circledR}(0.019-\mathrm{mg} \text { fluocinolone } \\
\text { acetonide implant })^{\mathrm{b}, \mathrm{c}}\end{array}$ & $\begin{array}{l}\text { nonbiodegra- } \\
\text { dable }\end{array}$ & $24-36$ & $\begin{array}{l}20 \% \text { gained at least } 15 \\
\text { letters by month } 12\end{array}$ & data not available & $0-5.9 \%$ & $15-29 \%$ \\
\hline $\begin{array}{l}\text { Methotrexate }(400 \mu g \\
\text { intravitreal injection) }\end{array}$ & - & 4 & $\begin{array}{l}87 \% \text { gained at least } 10 \\
\text { letters by month } 3\end{array}$ & yes & none & none \\
\hline Sirolimus (intravitreal injection) & - & 2 & $37 \%$ & yes & none & none \\
\hline $\begin{array}{l}\text { Biologicals } \\
\text { (anti-TNF } \alpha \text {, infliximab) }\end{array}$ & - & $\begin{array}{l}\text { data not } \\
\text { available }\end{array}$ & $\begin{array}{l}\text { improved from } 0.67 \pm 0.56 \\
\text { to } 1.37 \pm 0.43 \text { by week } 4\end{array}$ & data not available & none & none \\
\hline
\end{tabular}

19]. Long-term control of intraocular inflammation without relapses may result in less retinal damage and reduce the risk of visual loss. Implantable devices in the vitreous can deliver a constant concentration of medication over prolonged periods of time (table 2). Whereas nonbiodegradable, long-term delivery systems seem preferable for chronic diseases, shorter-lasting biodegradable products are preferred for conditions that require shortterm therapy, including CME. The profile of adverse effects following repeated applications still has to be evaluated [7].

\section{Fluocinolone Acetonide Implants}

Retisert ${ }^{\circledR}$ (Bausch \& Lomb, $0.59 \mathrm{mg}$ ) is currently the only FDA-approved fluocinolone acetonide implant. It is applied in uveitis, diabetic macular edema (DME) and retinal vein occlusion $[3,4,20,21]$. Several studies have demonstrated its efficacy in reducing recurrence, improving vision and reducing the need for systemic immunosuppressive medication in many types of posterior uveitis and panuveitis $[3,4]$. However, the incidences of cataract and glaucoma are significantly high (table 3).

Iluvien ${ }^{\circledR}$ (Alimera Sciences Inc.) is another FA intravitreal implant, which is designed to deliver CS to the retina for up to 3 years as a treatment for DME [26]. It uses the same drug matrix as Retisert, but is thought to release a lower dose of medication $(0.2$ or $0.5 \mu \mathrm{g} /$ day $)$, and is injected through a proprietary 25 -gauge injector system in an outpatient setting [26]. Phase III studies in DME have been completed with positive results. Preliminary data suggest that the risk of secondary IOP increase might be lower than with Retisert. Its use in CNIU is currently under clinical investigation.

\section{Dexamethasone Implant}

The commercial preparation of dexamethesone implant is Ozurdex ${ }^{\circledR}$ (Allergan, Inc., Irvine, Calif., USA; 0.7 $\mathrm{mg})$. Published phase III trials were carried out to treat retinal vein occlusion, DME and uveitis [23, 27, 28]. Following a single intravitreal injection, a lower incidence of cataracts and rise in IOP was reported in the Huron trial than with Retisert (table 3) [23]. These observations were more recently confirmed by our own observations and are particularly important in our young patients affected by CNIU. The dexamethasone implant seems to be a useful alternative to control vitreous haze and CME, although repeated implants may be necessary to prevent recurrence $[23,29]$. 
Table 3. Treatment effect of intravitreal drug delivery systems in studies with noninfectious uveitis

\begin{tabular}{|c|c|c|c|c|c|c|}
\hline & \multicolumn{2}{|c|}{$\begin{array}{l}\text { Retisert } \\
\text { (0.59-mg fluocinolone acetonide implant) }\end{array}$} & \multicolumn{2}{|c|}{$\begin{array}{l}\text { Ozurdex } \\
\text { (0.7-mg dexamethasone implant) }\end{array}$} & \multicolumn{2}{|c|}{$\begin{array}{l}\text { Methotrexate } \\
\text { (400- } \mu \text { g intravitreal injection) }\end{array}$} \\
\hline & $\begin{array}{l}\text { Callanan } \\
\text { et al. } 2008[4]\end{array}$ & $\begin{array}{l}\text { Pavesio } \\
\text { et al. } 2010[3]\end{array}$ & $\begin{array}{l}\text { Williams } \\
\text { et al. } 2009 \text { [22] }\end{array}$ & $\begin{array}{l}\text { Lowder } \\
\text { et al. } 2011[23]\end{array}$ & $\begin{array}{l}\text { Taylor } \\
\text { et al. } 2009 \text { [24] }\end{array}$ & $\begin{array}{l}\text { Bae and Lee } \\
2012[25]\end{array}$ \\
\hline Study design & $\begin{array}{l}\text { multicenter, } \\
\text { randomized, } \\
\text { historically } \\
\text { controlled trial }\end{array}$ & $\begin{array}{l}\text { randomized, controlled, } \\
\text { phase IIb/III, open-label, } \\
\text { multicenter superiority } \\
\text { trial }\end{array}$ & $\begin{array}{l}\text { randomized, } \\
\text { prospective, } \\
\text { single-masked, } \\
\text { controlled trial }\end{array}$ & $\begin{array}{l}\text { randomized, } \\
\text { prospective, } \\
\text { multicenter, masked }\end{array}$ & $\begin{array}{l}\text { prospective, } \\
\text { consecutive, } \\
\text { interventional } \\
\text { case series }\end{array}$ & retrospective \\
\hline Number of patients & 110 & 66 & 41 & 77 & 15 & 7 \\
\hline Follow-up period & 3 years & 3 years & 6 months & 6 months & 6 months & $\begin{array}{l}24.9 \pm 8.2 \\
\text { weeks }\end{array}$ \\
\hline $\begin{array}{l}\text { Uveitis recurrence rates during } \\
1 \text {-year period before treatment }\end{array}$ & $62 \%$ & not mentioned & not mentioned & not mentioned & not mentioned & not mentioned \\
\hline $\begin{array}{l}\text { Uveitis recurrence rates after } \\
\text { treatment }\end{array}$ & $\begin{array}{r}4 \% \text { (1-year) } \\
10 \% \text { (2-year) } \\
20 \% \text { (3-year) }\end{array}$ & $34.8 \%$ (2-year) & not mentioned & not mentioned & $33.3 \%$ & $28.6 \%$ \\
\hline Decrease in macular thickness & not mentioned & not mentioned & not mentioned & $\begin{array}{l}99.4 \mu \mathrm{m} \text { (after } 2 \\
\text { months) }\end{array}$ & $150 \mu \mathrm{m}$ & not mentioned \\
\hline $\begin{array}{l}\text { Improvement in fluorescein } \\
\text { leakage }\end{array}$ & not mentioned & not mentioned & $58 \%$ & not mentioned & not mentioned & $57 \%$ \\
\hline $\begin{array}{l}\text { Improvement in visual acuity } \\
\text { (at least } 3 \text { lines) }\end{array}$ & $23 \%$ & $17.2 \%$ & $53.8 \%$ & $40 \%$ (approximately) & $\begin{array}{l}87 \% \text { (at least } \\
2 \text { lines) }\end{array}$ & $85.7 \%$ \\
\hline $\begin{array}{l}\text { Reduction in the number of } \\
\text { patients requiring systemic } \\
\text { medications }\end{array}$ & $80 \%$ & not mentioned & not mentioned & not mentioned & $42.6 \%$ & $42.9 \%$ \\
\hline Cataract surgery & $93 \%$ & $87.8 \%$ & not mentioned ${ }^{\mathrm{a}}$ & $1.3 \%$ & none & none \\
\hline Glaucoma surgery & $40 \%$ at 3 -year & $21.2 \%$ & none & none $e^{b}$ & none & none \\
\hline
\end{tabular}

\section{Intravitreal Methotrexate Injection}

In an attempt to avoid the ocular side effects of intraocular CS, recent attention has been focused on alternative agents. One of these is methotrexate (MTX). The systemic use of MTX is standard care in conditions like in juvenile rheumatoid arthritis-associated uveitis because of its excellent safety record [30]. Intravitreal MTX was first administered as a therapy for intraocular lymphomas [31]. In addition, case series have shown the promising effects of intravitreal injection of $0.4 \mathrm{mg}$ MTX for CNIU and uveitic CME without significant ocular complications (table 3) [24, 32]. Recently, a biodegradable microneedle MTX implant inserted into deep lamellar scleral pockets was tested without any intra- or postsurgical complications or toxic effects [33].

Intravitreal Treatment of Noninfectious Uveitis

\section{Anti-Vascular Endothelial Growth Factor Agents}

Intravitreal anti-VEGF drugs are widely used to treat age-related choroidal neovascularization, DME and retinal vein occlusion edema [34-36]. They also successfully reduce choroidal neovascularization secondary to inflammation such as toxoplasmosis, punctate inner choroidopathy, serpiginous choroidopathy and multifocal choroiditis $[37,38]$. They have ambiguous results in the treatment of uveitic macular edema [36, 39, 40].

Intravitreal bevacizumab and ranibizumab were reported to improve visual acuity and to reduce CME in optical coherence tomography and fluorescein angiography images [36, 39]. Both agents may be a supplementary off-label therapeutic option for persistent uveitic CME [25]. They hold little risk of increasing IOP, and thus seem to be a treatment option for patients known as CS re- 
sponders. However, reinjection may be required because of their limited potency and short intravitreal half-life. When compared to IVTA injection, visual acuity and CME were more effectively treated with CS when compared to intravitreal bevacizumab in refractory CNIU at 6 months [40].

\section{Anti-Tumor Necrosis Factor- $\alpha$}

Systemic anti-tumor necrosis factor $\alpha(\mathrm{TNF} \alpha)$ agents represent a significant advance in the treatment of many inflammatory diseases. The therapeutic effects of systemic anti-TNF $\alpha$ agents for various types of uveitis, particularly Behçet disease, has been repeatedly shown [41].

Intraocular injection of anti-TNF $\alpha$ agents was proposed to avoid the systemic side effects. Several experimental studies demonstrated the safety of intraocular infliximab [42]. There are a few case series reporting the effectiveness of infliximab in human eyes. Farvardin et al. [43] showed visual acuity improvement and macular thickness reduction in patients with CNIU. However, intravitreal infliximab causes immunogenic reactions and probably retinotoxicity which may limit its use [44].

\section{Sirolimus}

Sirolimus (rapamycin) has potent immunosuppressive, antiangiogenetic and antiproliferative properties. Oral sirolimus was reported to be effective in the treat- ment of CNIU. However, multiple gastrointestinal and dermatological side effects have been observed [45]. Subsequent experimental intravitreal applications of sirolimus were well tolerated and nontoxic to the retina [46]. Phase I/II studies using different dosages are currently underway and will highlight the effectiveness and safety of intravitreal sirolimus in CNIU [47].

\section{Conclusion}

Currently, we are facing a 'boost' of new options in the treatment of CNIU. Whereas for many years, a gap of approved treatments was a dilemma for clinicans, there is now a notable interest from the pharmaceutical industry. Significant efforts are focusing on both more selective interventions using targeted systemic immunomodulation and novel techniques for local sustained drug delivery. As so often in ophthalmology, more well-designed randomized studies are needed to provide the right answer with regard to how to act....more local?

\section{Acknowledgement}

D.H. received research funding from TUBITAK (The Scientific and Technological Research Council of Turkey).

\section{References}

1 Gregerson DS, Heuss ND, Lehmann U, McPherson SW: Evidence for extrathymic generation of regulatory $\mathrm{T}$ cells specific for a retinal antigen. Ophthalmic Res 2008;40: 154-159.

-2 Kempen JH, Altaweel MM, Holbrook JT, Jabs DA, Louis TA, Sugar EA, Thorne JE: Randomized comparison of systemic antiinflammatory therapy versus fluocinolone acetonide implant for intermediate, posterior, and panuveitis: the Multicenter Uveitis Steroid Treatment trial. Ophthalmology 2011;118:1916-1926.

- 3 Pavesio C, Zierhut M, Bairi K, Comstock TL, Usner DW: Evaluation of an intravitreal fluocinolone acetonide implant versus standard systemic therapy in noninfectious posterior uveitis. Ophthalmology 2010;117:567575.

4 Callanan DG, Jaffe GJ, Martin DF, Pearson PA, Comstock TL: Treatment of posterior uveitis with a fluocinolone acetonide implant: three-year clinical trial results. Arch Ophthalmol 2008;126:1191-1201.
Razeghinejad MR, Katz LJ: Steroid-induced iatrogenic glaucoma. Ophthalmic Res 2012 47:66-80.

6 Menezo V, Lau C, Comer M, Lightman S: Clinical outcome of chronic immunosuppression in patients with non-infectious uveitis. Clin Exp Ophthalmol 2005;33:16-21.

7 Sallam A, Taylor SRJ, Lightman S: Review and update of intraocular therapy in noninfectious uveitis. Curr Opin Ophthalmol 2011;22:517-522.

-8 Roesel M, Gutfleisch M, Heinz C, Heimes B, Zurek-Imhoff $\mathrm{B}$, Heiligenhaus A: Intravitreal and orbital floor triamcinolone acetonide injections in noninfectious uveitis: a comparative study. Ophthalmic Res 2009;42: 81-86.

-9 Maca SM, Abela-Formanek C, Kiss CG, Sacu SG, Benesch T, Barisani-Asenbauer T: Intravitreal triamcinolone for persistent cystoid macular oedema in eyes with quiescent uveitis. Clin Exp Ophthalmol 2009;37:389-396.
10 Sallam A, Taylor SR, Habot-Wilner Z, Elgohary M, Do HH, McCluskey P, Lightman S: Repeat intravitreal triamcinolone acetonide injections in uveitic macular oedema. Acta Ophthalmol 2012;90:e323-e325.

- 11 Tuncer S, Yilmaz S, Urgancioglu M, TugalTutkun I: Results of intravitreal triamcinolone acetonide (IVTA) injection for the treatment of panuveitis attacks in patients with Behçet disease. J Ocul Pharmacol Ther 2007; 23:395-401.

12 Chan WM, Lim E, Liu DT, Law RW, Lam DS: Intravitreal triamcinolone acetonide for choroidal granuloma in sarcoidosis. Am J Ophthalmol 2005;139:1116-1118.

13 Moreker MR, Lodhi SA, Pathengay A: Role of intravitreal triamcinolone as an adjuvant in the management of Vogt-Koyanagi-Harada disease. Indian J Ophthalmol 2007;55: 479-80.

14 Ozdemir H, Karacorlu M, Karacorlu S: Intravitreal triamcinolone acetonide in sympathetic ophthalmia. Graefes Arch Clin Exp Ophthalmol 2005;243:734-736. 
15 Jonas JB: Intravitreal triamcinolone acetonide: a change in a paradigm. Ophthalmic Res 2006;38:218-245.

16 Rush R, Sheth S: Fulminant toxoplasmic retinochoroiditis following intravitreal triamcinolone administration. Indian J Ophthalmol 2012;60:141-143.

17 Vertes D, Snyers B, De Potter P: Cytomegalovirus retinitis after low-dose intravitreous triamcinolone acetonide in an immunocompetent patient: a warning for the widespread use of intravitreous corticosteroids. Int Ophthalmol 2010;30:595-597.

- 18 Nguyen QD, Callanan D, Dugel P, Godfrey DG, Goldstein DA,Wilensky JT: Treating chronic noninfectious posterior segment uveitis: the impact of cumulative damage. Proceedings of an expert panel roundtable discussion. Retina 2006;(suppl):1-16.

19 Arndt C, Meunier I, Rebollo O, Martineng C, Hamel C, Hattenbach LO: Electrophysiological retinal pigment epithelium changes observed with indocyanine green, trypan blue and triamcinolone. Ophthalmic Res 2010;44:17-23

-20 Morse LS, Ashton P, Levy B, Mann ES, Eliott D: Fluocinolone acetonide intravitreal implant for diabetic macular edema: a 3- year multicenter, randomized, controlled clinical trial. Ophthalmology 2011;118:1580-1586.

-21 Jain N, Stinnett SS, Jaffe GJ: Prospective study of a fluocinolone acetonide implant for chronic macular edema from central retinal vein occlusion thirty-six-month results. Ophthalmology 2012;119:132-137.

22 Williams GA, Haller JA, Kuppermann BD, Blumenkranz MS, Weinberg DV, Chou C, Whitcup SM, Dexamethasone DDS Phase II Study Group: Dexamethasone posteriorsegment drug delivery system in the treatment of macular edema resulting from uveitis or Irvine-Gass syndrome. Am J Ophthalmol 2009;147:1048-1054, 1054.e1-e2.

- 23 Lowder C, Belfort R Jr, Lightman S, Foster CS, Robinson MR, Schiffman RM, Li XY, Cui H, Whitcup SM, Ozurdex HURON Study Group: Dexamethasone intravitreal implant for noninfectious intermediate or posterior uveitis. Arch Ophthalmol 2011; 129:545-553.

-24 Taylor SR, Habot-Wilner Z, Pacheco P, Lightman SL: Intraocular methotrexate in the treatment of uveitis and uveitic cystoid macular edema. Ophthalmology 2009;116: 797-801.

25 Bae JH, Lee SC: Effect of intravitreal methotrexate and aqueous humor cytokine levels in refractory retinal vasculitis in Behcet disease. Retina 2012;32:1395-402.

-26 Campochiaro PA, Hafiz G, Shah SM, Bloom S, Brown DM, Busquets M, Ciulla T, Feiner L, Sabates N, Billman K, Kapik B, Green K, Kane F, Famous Study Group: Sustained ocular delivery of fluocinolone acetonide by an intravitreal insert. Ophthalmology 2010;117: 1393-1399.e3.
27 Haller JA, Bandello F, Belfort R Jr, Blumenkranz MS, Gillies M, Heier J, Loewenstein A, Yoon Y- H, Jacques M- L, Jiao J, Li X- Y, Whitcup SM: Randomized, sham-controlled trial of dexamethasone intravitreal implant in patients with macular edema due to retinal vein occlusion. Ophthalmology 2010;117: 1134-1146, e1133.

28 Boyer DS, Faber DJ, Gupta SK, Patel SS, Ta bandeh H, Li XY, Liu CC, Lou J, Whitcup SM, the Ozurdex Champlain Study Group: Dexamethasone intravitreal implant for treatment of diabetic macular edema in vitrectomized patients. Retina 2011;31:915923.

29 Pleyer U, Klamann M, Winterhalter S, Thurau S: Ozurdex: a new therapeutic option in uveitis - clinical outcome from two German uveitis centers. Abstract ARVO Annual Meeting, Fort Lauderdale, May 2012.

30 Dueckers G, Guellac N, Arbogast M, Dannecker G, Foeldvari I, Frosch M, Ganser G, Heiligenhaus A, Horneff G, Illhardt A, Kopp I, Krauspe R, Markus B, Michels H, Schneider M, Singendonk W, Sitter H, Spamer M, Wagner N, Niehues T: Evidence and consensus based GKJR guidelines for the treatment of juvenile idiopathic arthritis. Clin Immunol 2012;142:176-193

-31 Wickremasinghe SS, Ojaimi E, Lim L, Stawell R, McKelvie P, Zamir E: Intravitreal methotrexate as adjunctive, palliative therapy in intraocular T-cell lymphoma. Ocul Immunol Inflamm 2010;18:184-186.

-32 Hardwig PW, Pulido JS, Erie JC, Baratz KH, Buettner H: Intraocular methotrexate in ocular diseases other than primary central nervous system lymphoma. Am J Ophthalmol 2006;142:883-885.

33 Palakurthi NK, Correa ZM, Augsburger JJ, Banerjee RK:Toxicity of a biodegradable microneedle implant loaded with methotrexate as a sustained release device in normal rabbit eye: a pilot study. J Ocul Pharmacol Th 2011; 27:151-156.

34 Patel RD, Momi RS, Hariprasad SM: Review of ranibizumab trials for neovascular agerelated macular degeneration. Semin Ophthalmol 2011;26:372-379.

35 El-Mollayess GM, Noureddine BN, Bashshur ZF: Bevacizumab and neovascular age related macular degeneration: pathogenesis and treatment. Semin Ophthalmol 2011;26:6976. M, Chevez-Barrios P, Takahashi W: Testing intravitreal toxicity of rapamycin in rabbit eyes. Arq Bras Oftalmol 2009;72:18-22.
47 Nguyen QD, Ibrahim M, Watters A: Primary endpoint results of the SAVE study - siroli- mus as therapeutic approach to uveitis: a ran- domized study to assess the safety and bioac- tivity of intravitreal and subconjunctival injections of sirolimus in patients with non- infectious uveitis. Abstract ARVO Annual Meeting, Fort Lauderdale, May 2012.

